\title{
Listeria monocytogenes meningitis and decreased phagocytosis associated with iron overload
}

\author{
B SWEDER VAN ASBECK, HENRI A VERBRUGH, BERNARD A VAN OOST, JO J M MARX, \\ HANS W IMHOF, JAN VERHOEF
}

\begin{abstract}
A patient with Listeria monocytogenes meningitis was found to have idiopathic haemochromatosis and monocytes with reduced phagocytic capacity. The phagocytic function recovered completely after a series of therapeutic phlebotomies. In-vitro iron had a deleterious effect on the phagocytic capacity of monocytes and granulocytes.
\end{abstract}

These findings show that iron overload in the host can increase susceptibility to $L$ monocytogenes infection not only by increasing the virulence of the organism but also by reducing the phagocytic capacity of the monocytes.

\section{Introduction}

Listeria monocytogenes is often found as a commensal in healthy individuals. ${ }^{1}$ Infections by Listeria are uncommon and are usually restricted to neonates, the aged, and patients with a suppressed immune response. ${ }^{2} L$ monocytogenes infections have been described in patients with haemochromatosis and other conditions which may be complicated by an excess of iron, such as alcoholism and hepatic and haematological diseases. ${ }^{1-6}$ Iron is essential for microbial growth, and extreme plasma iron saturation can enhance the virulence of micro-organisms by permitting proliferation beyond a level that can be controlled by the host. ${ }^{78}$ The agents of resistance to $L$ monocytogenes are the cells of the mononuclear phagocytic system ${ }^{9}$ so we studied phagocytic cell function in a patient with idiopathic haemochromatosis and $L$ monocytogenes meningitis before and after treatment by phlebotomy. The results were consistent with the results obtained in an in vitro study on the influence of iron on phagocytosis.

\section{Case report}

A 58 -year-old man was admitted because of fever $\left(40 \cdot 2^{\circ} \mathrm{C}\right)$, progressively severe headache, and disorientation. He had a history of a duodenal ulcer, recurrent furunculosis, and chest pain on exertion for the last six years. His blood pressure was $150 / 100 \mathrm{~mm} \mathrm{Hg}$. Physical examination showed a greyish skin with many scars of furuncles. The neck was rigid in all directions. The lungs and heart were normal. The edge of the liver was felt $8 \mathrm{~cm}$ below the right costal margin. The spleen was not palpable. The tendon reflexes were positive.

Initial laboratory studies showed an erythrocyte sedimentation rate of $25 \mathrm{~mm}$ after one hour. The haemoglobin concentration was 15.9 $\mathrm{g} / \mathrm{dl}$, the packed cell volume $52 \%$, the white blood-cell count $20 \cdot 3 \times$ $10^{9} / 1$ (with $68^{\circ}{ }_{0}$ neutrophils, $7 \%$ band forms, $18 \%$ lymphocytes, $7 \%$

Departments of Internal Medicine, Microbiology, and Haematology, University Hospital, Utrecht, The Netherlands

B $S$ VAN ASBECK, MD, research fellow

H A VERBRUGH, MD, bacteriologist (present appointment: University of Minnesota, Minneapolis, USA)

B A vAN OOST, PHD, biochemist

J J M MARX, MD, consultant haematologist

$\mathrm{J}$ VERHOEF, MD, professor of clinical bacteriology

Department of Internal Medicine, De Lichtenberg Hospital, Amersfoort, The Netherlands

HANS W IMHOF, MD, consultant physician monocytes), and the platelet count $102 \times 10^{9} / 1$. The urine was positive for glucose and urobilin. Renal function was normal. Glucose was 12.0 $\mathrm{mmol} / \mathrm{l}(216 \mathrm{mg} / 100 \mathrm{ml})$, total bilirubin $33 \mu \mathrm{mol} / \mathrm{l}(1.9 \mathrm{mg} / 100 \mathrm{ml})$ with $36 \%$ conjugated bilirubin, alkaline phosphatase $71 \mathrm{U} / \mathrm{l}$, aspartate aminotransferase (AST) $61 \mathrm{U} / 1$, and alanine aminotransferase (ALT) $37 \mathrm{U} / 1$. A lumbar puncture yielded yellow cerebrospinal fluid containing numerous Gram-positive rods, identified after culture as $L$ monocytogenes type $4 \mathrm{~b}$. The serum agglutination titre for $L$ monocytogenes was $1 / 1280$. Immunological studies showed normal E-rosette formation for lymphocytes, positive delayed-type hypersensitivity reactions for Candida and purified protein derivative of tuberculin, and a mild increase in the gammaglobulin concentration. The dinitrochlorobenzene score after sensitisation was normal.

The patient was treated with ampicillin. Insulin was administered concurrently because of raised blood sugar values. His condition improved rapidly and he had an uneventful convalescence, but his liver function values remained abnormal. Radionuclide scanning showed an enlarged liver with a homogeneous distribution of the radioactivity. A liver biopsy specimen showed changes consistent with cirrhosis and a considerable increase in stainable iron in the hepatocytes and Kupffer cells. Further laboratory examinations showed a serum iron concentration of $31 \mu \mathrm{mol} / 1(173 \mu \mathrm{g} / 100 \mathrm{ml})$, a total ironbinding capacity of $49 \mu \mathrm{mol} / 1(273 \mu \mathrm{g} / 100 \mathrm{ml})$, and a saturation of $63 \%$. Serum transferrin was $1.95 \mathrm{~g} / \mathrm{l}$ and serum ferritin $2050 \mu \mathrm{g} / \mathrm{l}$ (normal range in our laboratory $15-150 \mu \mathrm{g} / \mathrm{l}$ ). After an intramuscular injection of $1000 \mathrm{mg}$ desferrioxamine the iron excretion in the urine was 40 $\mu \mathrm{mol} / 24 \mathrm{~h}(2234 \mu \mathrm{g} / 24 \mathrm{~h})$. In the bone marrow the iron stores were not increased and sideroblasts were normal. Study of iron absorption after ingestion of a $1-\mathrm{mg} \mathrm{Fe}^{++}$carrier dose showed high values for mucosal uptake $(72 \cdot 3 \%)$, iron retention $(69.9 \%)$, and the mucosal transport fraction (0.96), as found in iron deficiency and also in idiopathic haemochromatosis. ${ }^{10}$ On the basis of these findings we diagnosed $L$ monocytogenes meningitis, idiopathic haemochromatosis, and diabetes mellitus. A series of phlebotomies was performed. During the first month $500 \mathrm{ml}$ of blood was removed weekly, and the interval was then increased to a fortnight because the patient complained of angina pectoris. After six months the serum ferritin concentration had fallen to $1017 \mu \mathrm{g} / \mathrm{l}$ and after 14 months to $62 \mu \mathrm{g} / \mathrm{l}$.

\section{Methods}

Before treating this patient's haemochromatosis we studied his phagocytic cell function. Phagocytosis by human mononuclear and polymorphonuclear leucocytes was assessed according to a method described elsewhere. ${ }^{11}$ In brief, human mononuclear and polymorphonuclear leucocytes were incubated at $37^{\circ} \mathrm{C}$ with ${ }^{3} \mathrm{H}$-thymidine labelled, opsonised Staphylococcus aureus at a bacteria-to-leucocyte ratio of 10:1. After washing, leucocyte-associated radioactivity was determined after 2, 6, and 12 minutes, and phagocytosis was expressed as a percentage of the total radioactivity added. To exclude experimental errors-for example, from radioactive labelling of staphylococci-we tested the phagocytic function of mononuclear and polymorphonuclear leucocytes from healthy controls at the same time as that of the patient. The normal range of phagocytosis was ascertained as the $95 \%$ confidence interval obtained with mononuclear and polymorphonuclear leucocytes from 48 and 59 healthy donors respectively.

The phagocytic activity of the patient's leucocytes was assayed after he had recovered from the meningitis, together with that of control mononuclear and polymorphonuclear leucocytes. Three tests were performed in duplicate sequentially over six months with a two-month interval before the start of therapeutic phlebotomies. The assay was performed again after six, seven, and 13 months of phlebotomy. Throughout the period in which the tests were done the blood glucose concentration was well controlled with insulin, no other medication was given, and the patient was free of infection.

To detect any effect of iron on the phagocytic capacity of normal donor mononuclear and polymorphonuclear leucocytes these cells 
were preincubated in $\mathrm{RPMI}_{1640}$ (Gibco) containing ferric citrate (Merck) at final concentrations of $0,0.05,0 \cdot 1,0 \cdot 15$, and $0.2 \mathrm{mmol} / \mathrm{l}$. For this purpose, ferric citrate, at equal molar concentrations of iron and citrate, was dissolved in distilled water to a concentration of 20 $\mathrm{mmol} / \mathrm{l}$. At neutral $\mathrm{pH}$ this iron compound forms polynuclear complexes. ${ }^{12-14}$ The iron content of the solution was checked by a spectrophotometric assay using Ferrozin $(\mathrm{BDH})$ as complexing agent. After 20 hours of incubation at $37^{\circ} \mathrm{C}$ in air containing $5 \%$ carbon dioxide the cells were washed twice and resuspended in RPMI ${ }_{1640}$ for the assessment of phagocytosis and of cell viability, which was tested by trypan blue dye exclusion $\left(0 \cdot 2^{\circ}\right.$ trypan blue dye). The effect of ferritin on phagocytosis by normal donor leucocytes was also investigated, because the patient had a high serum ferritin concentration. This study was performed with ferritin in final concentrations of 750, 1500,3000, and $6000 \mu \mathrm{g} / 1$, using partially purified serum ferritin from the patient's plasma, obtained from the first phlebotomies, according to methods described elsewhere. ${ }^{15}{ }^{16}$ Results were examined statistically by two-way analysis of variance. ${ }^{17}$

\section{Results}

In all tests the phagocytic function of the patients polymorphonuclear leucocytes was within the normal range and there was no difference from that of control leucocytes. The mean values for phagocytosis by the patient's mononuclear leucocytes, however, were at the lower limit of normal and were significantly lower than those of the control mononuclear leucocytes $(p<0 \cdot 01)$ (see table). After removal of iron by phlebotomy over six months, however, which decreased the serum ferritin concentration from 2050 to $1017 \mu \mathrm{g} / \mathrm{l}$, uptake of Staphylococcus aureus by the patient's mononuclear leucocytes after 2,6 , and 12 minutes' incubation was significantly improved $(p<0.02)$ (see table). More than $80^{\circ}$ of the added bacteria were phagocytised by the mononuclear leucocytes after 12 minutes of incubation compared with only $45 \%$ before the therapeutic phlebotomies.

Incubation of the normal donors' mononuclear and polymorphonuclear leucocytes with various concentrations of iron showed a dosedependent inhibition of the phagocytic capacity of both types of cell (see figure). At a concentration of $0 \cdot 2 \mathrm{mmol} / \mathrm{l}$ ferric citrate the inhibition was about $60 \%$. After incubation with $0.05 \mathrm{mmol} / \mathrm{l}$ ferric citrate the phagocytic capacity was not significantly reduced. No effect was seen when $0.2 \mathrm{mmol} / 1$ sodium citrate was used. Viability of the mononuclear $(87-93 \%)$ and polymorphonuclear leucocytes $(85-92 \%)$ after exposure to iron was no different from that of the control leucocytes $88-93 \%$ and $86-94 \%$ respectively).

To study the effect of the high serum ferritin concentration on phagocytosis, we isolated ferritin from the patient's plasma obtained during the first phlebotomies and incubated normal donor leucocytes as well. The phagocytic capacity of the leucocytes did not decrease, even after 20 hours of incubation in a culture medium containing $6000 \mu \mathrm{g} / \mathrm{l}$ ferritin.

\section{Discussion}

Listeria monocytogenes is a ubiquitous organism which is often present in healthy individuals but may be pathogenic under certain conditions - for example, in patients with impaired host resistance. ${ }^{12}$ Infection is almost always due to haemolytic

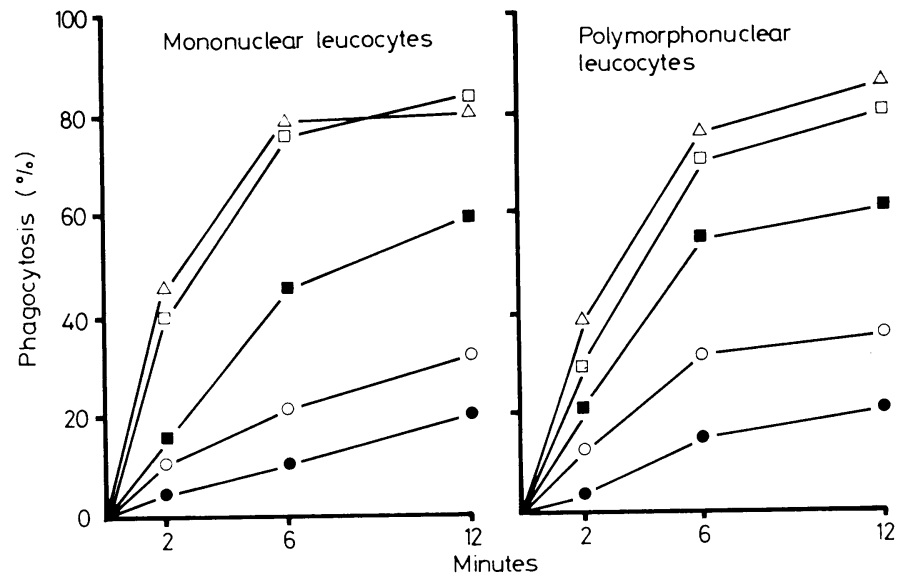

Effect of increasing concentration of iron on phagocytosis of Staph aureus by mononuclear and polymorphonuclear leucocytes. Leucocytes were preincubated during 20 hours with various concentrations of ferric citrate $(0 \mathrm{mmol} / 1: \triangle-\triangle ; 0.05 \mathrm{mmol} / 1: \square-\square ; 0.1 \mathrm{mmol} / \mathrm{l}: \square-\mathbf{\square} ; 0.15 \mathrm{mmol} / \mathrm{l}$ $0-0 ; 0.2 \mathrm{mmol} / 1$ : - - ). Percentage phagocytosis represents the percentage of opsonised bacteria taken up by the leucocytes after 2,6 , and 12 minutes of incubation.

$L$ monocytogenes strains of the well-known serotypes I and $4 \mathrm{~b} .^{1}$ Various clinical syndromes have been described in listerosis, but the nervous system is the most commonly affected system, ${ }^{2}$ as was the case in our patient, who also had iron overload.

Studies in vivo have shown that iron plays an important part in the host resistance to $L$ monocytogenes. When iron compounds were injected the median lethal dose of $L$ monocytogenes in mice dropped from about $3 \times 10^{3}$ to about $5 .{ }^{18}$ When added to a synthetic medium, iron stimulated in-vitro growth of the microorganism. ${ }^{18}$ Iron is essential for microbial growth, and an increase in the availability of iron in the host's tissues is an important determinant of the nature of the infection produced by potential pathogens and their virulence. ${ }^{8}$ The demonstration in animals that iron compounds enhance the virulence of mycobacteria, listeria, yersiniae, staphylococci, clostridia, several enterobacteria, ${ }^{19}$ and gonococci, ${ }^{20}$ supports the view that iron metabolism in the host plays a part in the onset and progression of bacterial infections.

Resistance to infection by intracellular organisms such as $L$ monocytogenes is thought to depend primarily on cell-mediated immunity. ${ }^{21}$ Thymus-derived lymphocytes have been shown in vitro to play an important part in the activation of monocytes and macrophages to kill listeria. ${ }^{9223}$ In our patient, however, tests of cellular immunity gave normal results, and this led us to evaluate the function of his mononuclear phagocytic system. The concurrent haemochromatosis also prompted us to investigate the effect of iron on phagocytic cells.

The patient's mononuclear and polymorphonuclear leucocytes were studied over six months after he had recovered from

Mean (-SEM) values for phagocytosis of Staph aureus by mononuclear and polymorphonuclear leucocytes obtained from patient and controls after various incubation times. Also shown is the normal range for leucocyte phagocytic capacity (95\% confidence intervals)

\begin{tabular}{|c|c|c|c|c|c|c|c|c|c|c|}
\hline \multirow{4}{*}{$\begin{array}{l}\text { Incubation } \\
\text { time } \\
(\mathrm{min})\end{array}$} & \multicolumn{10}{|c|}{ Phagocytosis (\%)* } \\
\hline & \multicolumn{4}{|c|}{ Patient } & \multicolumn{4}{|c|}{ Controls $(n=3)$} & & \\
\hline & \multicolumn{2}{|c|}{$\underset{\text { treatment }}{\text { Before }}$} & \multicolumn{2}{|c|}{$\begin{array}{l}\text { After removal of } \\
3500 \mathrm{mg} \text { iron by } \\
\text { phlebotomy }\end{array}$} & \multicolumn{2}{|c|}{$\begin{array}{c}\text { Before } \\
\text { treatment }\end{array}$} & \multicolumn{2}{|c|}{$\begin{array}{l}\text { After } \\
\text { treatment }\end{array}$} & \multicolumn{2}{|c|}{ Normal range } \\
\hline & $\mathrm{MN}++$ & PMN & $\mathrm{MN}_{+}^{+}$ & PMN & $\mathrm{MN}+$ & PMN & $M N$ & PMN & $M N(n=48)$ & $\operatorname{PMN}(n=59)$ \\
\hline $\begin{array}{r}2 \\
6 \\
12\end{array}$ & 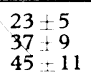 & $\begin{array}{l}50: 2 \\
80: 4 \\
80 \pm 3\end{array}$ & $\begin{array}{l}48 \div 3 \\
71=9 \\
84\end{array}$ & $\begin{array}{l}45 \pm 3 \\
78 \pm 5 \\
82 \pm 2\end{array}$ & $\begin{array}{l}48 \pm 4 \\
70 \pm 5 \\
80 \pm 4\end{array}$ & $\begin{array}{l}51 \pm 2 \\
83 \pm 3 \\
84 \pm 2\end{array}$ & $\begin{array}{l}47 \pm 1 \\
73 \pm 3 \\
81 \pm 2\end{array}$ & $\begin{array}{l}61 \pm 3 \\
83 \pm 3 \\
84 \pm 2\end{array}$ & $\begin{array}{l}39 \pm 22 \\
62 \pm 28 \\
71 \pm 24\end{array}$ & $\begin{array}{l}47 \pm 24 \\
84 \pm 15 \\
84 \pm 15\end{array}$ \\
\hline
\end{tabular}

$\mathrm{MN}=$ Mononuclear leucocytes. $\mathrm{PMN}=$ Polymorphonuclear leucocytes.

*Percentage phagocytosis represents the percentage of total amount of bacteria in the medium taken up by the leucocytes. Statistical differences between observations indicated by + and + were determined by using two-way analysis of variance.

$+\mathrm{p}<0.01 ; \neq \mathrm{p}<0.02$. 
meningitis. The phagocytic capacity of the mononuclear leucocytes was largely diminished, but polymorphonuclear function was normal. After removal of about $3500 \mathrm{mg}$ of iron by phlebotomy, however, the function of the mononuclear leucocytes returned to normal. All tests were carried out in duplicate and the patient's cells were tested several times before and after phlebotomy. When these sequential observations were taken into account the improved phagocytic capacity after removal of iron by phlebotomy was significant $(p<0.02)$.

In vitro we did not observe any effect of ferritin on the phagocytic function of leucocytes obtained from healthy controls. Nevertheless, iron had a dose-dependent inhibiting effect on phagocytosis after preincubation of control leucocytes in a medium containing ferric citrate. Concentrations of $0 \cdot 1-0 \cdot 15$ $\mathrm{mmol} / \mathrm{l}$ of iron caused a decrease of phagocytosis similar to that observed in the patient's mononuclear leucocytes. The effect of iron was not due to a decrease in the number of viable cells, since trypan blue was excluded just as well as in control cells. We used citrate in our tests because of its wide availability as a ligand for iron in biological systems. At physiological $\mathrm{pH}$ values equimolar amounts of iron and citrate form slow-reacting iron polymers where citrate ions provide a protective coating to prevent aggregation..$^{12}{ }^{13}$ Considering the behaviour of iron in aqueous solutions, we suspect that the non-transferrin and non-albuminbound iron observed in patients with primary and secondary haemochromatosis ${ }^{24-26}$ may be similar to these ferric citrate complexes. This non-specific plasma iron with potential toxicity, probably an inorganic iron complex, disappeared after removal of only a few grams of iron by phlebotomy. This probably occurred also in our patient, resulting in improvement of the mononuclear function. It is not clear why the function of only the patient's mononuclear leucocytes and not that of his polymorphonuclear leucocytes was impaired. This divergence might have been related to the degree of iron loading and to the difference in the time spent by mononuclear and polymorphonuclear leucocytes in the circulation.

There are several reports about the influence of iron on phagocyte function. ${ }^{27-29}$ Iron can enhance the ability of microorganisms to proliferate within polymorphonuclear leucocytes by lowering the bactericidal capacity. The mechanism of the inhibiting effect of iron on the leucocyte function is not clearly understood. Damage to cell structures by iron-catalysed freeradical oxidations might be an explanation. Iron has recently been shown to enhance the production of hydroxyl radicals by human neutrophils, ${ }^{30}$ and it has been suggested that hydroxyl radicals, one of the most potent oxidants known, ${ }^{31}$ play a part in the peroxidation of membrane lipids. ${ }^{32}$

Our findings indicate that an excess of iron in the host can enhance the susceptibility to $L$ monocytogenes infection, not only because of the increased availability of iron but also because of the resulting impairment of the function of the circulating mononuclear phagocytic cells.

We thank Miss Maeyken Hoeneveld for secretarial help. Part of this study was made possible by a grant from Ciba-Geigy, Basel, Switzerland.

\section{References}

${ }^{1}$ Kampelmacher EH, van Noorle Jansen LM. Listeriosis in humans and animals in the Netherlands (1958-1977). Zentralbl Bakteriol $[A] 1980$; 246:211-27.

2 Nieman RE, Lorber B. Listeriosis in adults : A changing pattern. Report of eight cases and review of the literature, 1968-1978. Rev Infect Dis 1980; 2:207-27.

${ }^{3}$ Green HT, Macaulay MB. Hospital outbreak of Listeria monocytogenes septicaemia: a problem of cross infection. Lancet 1978;ii:1039-40.

4 Sinkovics JG, Cormia F, Plager C. Hemachromatosis and Listeria infection. Arch Intern Med 1980;140:284.

5 Anonymous. Case record of the Massachusetts General Hospital (case 401978). N Engl f Med 1978;299:819-26.

6 MacDonald RA. Hemochromatosis. Postgrad Med 1967;41:56-64.

${ }^{7}$ Lankford CE. Bacterial assimilation of iron. CRC Crit Rev Microbiol 1973; 2:273-331
${ }^{8}$ Payne SM, Finkelstein RA. The critical role of iron in host-bacterial interactions. $\mathcal{f}$ Clin Invest $1978 ; 21: 1428-40$.

9 North RJ. Cell-mediated immunity and the response to infection. In : McCluskey RT, Cohen S, eds. Mechanism of cell-mediated immunity. New York: J Wiley and Sons, 1974:185-219.

${ }^{10}$ Marx JJM. Mucosal uptake, mucosal transfer and retention of iron, measured by whole-body counting. Scand $\mathcal{f}$ Haematol $1979 ; 23: 293-302$.

11 Verbrugh HA, Peters R, Peterson PK, Verhoef J. Phagocytosis and killing of staphylococci by human polymorphonuclear and mononuclear leucocytes. F Clin Pathol $1978 ; 31: 539-45$.

${ }^{12}$ Spiro TG, Pape L, Saltman P. The hydrolytic polymerization of ferric citrate. I. The chemistry of the polymer. F Am Chem Soc 1967;89: 5555-9.

${ }^{13}$ Spiro TG, Bates G, Saltman P. The hydrolytic polymerization of ferric citrate. II. The influence of excess citrate. F Am Chem Soc 1967;89: 5559-62.

14 Warner RC, Weber I. The cupric and ferric citrate complexes. $\mathcal{F}$ Am Chem Soc 1953;75:5086-96.

15 Worwood M, Dawkins S, Wagstaff $M$, Jacobs A. The purification and properties of ferritin from human serum. Biochem $\mathcal{f}$ 1976;157:97-103.

${ }_{16}$ Van Oost B, van den Beld B, Goedhart J, Sixma J. Antibody labelling by means of ${ }^{125}$ I-Protein A. In: Peters H ed. Protides of the biological fluids. Oxford and New York: Pergamon Press, 1979.

17 Dixon WJ, Massey FJ. Introduction to statistical analysis. Tokyo: McGrawHill, Kogakusha, 1969:150-92.

18 Sword CP. Mechanism of pathogenesis in Listeria monocytogenes infection. I. Influence of iron. 7 Bacteriol 1966;92:536-42.

19 Bullen JJ, Rogers HJ, Griffiths E. Bacterial iron metabolism in infection and immunity. In: Neilands JB ed. Microbial iron metabolism, a comprehensive treatise. New York: Academic Press, 517-51.

${ }^{20}$ Payne SM, Finkelstein RA. Pathogenesis and immunology of experimental gonococcal infection: role of iron in virulence. Infect Immunol $1975 ; 12: 1313-8$

${ }^{21}$ Mackaness GB. Resistance to intracellular infection. F Infect Dis 1971; $123: 439-45$.

${ }^{22}$ Krahenbuhl JL, Rosenberg LT, Remington JS. The role of thymusderived lymphocytes in the in vitro activation of macrophages to kill Listeria monocytogenes. $\mathcal{F}$ Immunol 1973;111:992-5.

${ }^{23}$ North RJ. T cell dependence of macrophage activation and mobilization during infection with mycobacterium tuberculosis. Infect Immunol 1974;10:66-71.

${ }^{24}$ Hershko Ch, Graham G, Bates GW, Rachmilewitz EA. Non-specific serum iron in thalassaemia: an abnormal serum iron fraction of potential toxicity. Br f Haematol 1978;40:255-63.

25 Batey RG, Lai Chung Fo P, Shamir S, Sherlock S. A non-transferrinbound serum iron in idiopathic hemochromatosis. Digest Dis Sci 1980; $25: 340-6$.

26 Fargion S, Cappelini MD, Sampietro M, Fiorelli G. Non-specific iron in patients with Beta-Thalassaemia trait and chronic active hepatitis. Scand 7 Haematol $1981 ; 26: 161-7$.

27 Weinberg ED. Iron and infection. Microbiol Rev 1978;42:45-66.

${ }^{28}$ Gladstone GP, Walton $\mathrm{E}$. The effect of iron and haematin on the killing of staphylococci by rabbit polymorphs. Br $\mathcal{F}$ Exp Pathol 1971;52:452-62.

${ }^{29}$ Kaplan SS, Quie PG, Basford RE. Effect of iron on leukocyte function: inactivation of $\mathrm{H}_{2} \mathrm{O}_{2}$ by iron. Infect Immunol 1975;12:303-8.

30 Ambruso DR, Johnston RB Jr. Lactoferrin enhances hydroxyl radical production by human neutrophils, neutrophil particulate fractions, and an enzymatic generating system. F Clin Invest $1981 ; 67: 352-60$.

31 Neta P, Dorfman LM. Pulse radiolysis studies XIII. Rate constants for the reaction of hydroxyl radical with aromatic compounds in aqueous solutions. Adv Chem Sci $1968 ; 81: 222-30$.

${ }^{32}$ Fong KL, McCay PB, Poyer JL, Keele BB, Misra H. Evidence that peroxidation of lysosomal membranes is initiated by hydroxyl free radicals produced during flavin enzyme activity. F Biol Chem 1973;248:7792-7.

(Accepted 26 October 1981)

ONE HUNDRED YEARS AGO Dr R A Jamieson of Shanghai has recently presented to the Museum of the Royal College of Surgeons a pair of feet, to which the following remarkable history is attached. Some months ago, a Chinese beggar excited much pity, and made a very profitable business in the streets of the foreign settlement, Shanghai, by showing the mutilated stumps of his legs, the feet belonging to them being tied together, and slung round his neck. Warned frequently by the police, he was knocked down by a carriage one day when scrambling out of the way of a constable. He was brought into hospital, under Dr Jamieson's care, being slightly injured; and, on recovery from his bruises, he sold to his medical attendant his feet, which otherwise would have been confiscated by the police. He admitted that, for the purpose of making himself as attractive as possible to the charitably disposed, he had, about a year previously, fastened cords round his ankles, drawing them as tight as he could bear them, and increasing the pressure every two or three days. In about a fortnight, the bones were bare, and he had no more pain. (British Medical fournal, 1882.) 